\title{
Blended Learning Approach to Develop the Teachers' TPACK
}

\author{
Arwa Ahmed Abdo Qasem \\ University of Mysore, India \\ Gandla Viswanathappa \\ Regional Institute of Education Mysore, India
}

\begin{abstract}
A theoretical framework has emerged recently to guide research in the teachers' use of ICT and it is the technological pedagogical content knowledge (TPACK). Early research indicates that Blended learning is increasingly being adopted at all levels of educational system. It is considered as a way to foster engaging in interactive learning experiences. The purpose of this article was to determine the levels of ICT knowledge on e-course design through blended learning approach among science teachers of secondary schools in Yemen. The study was conducted on the sample of 60 science teacher trainees in lbb city. The ICT knowledge scale was used based on TPACK. To analyze the data t-test was used. The findings in this study indicated that TPACK has provided a valuable tool for assessing teacher knowledge in the area of technology integration, the teachers' ICT knowledge was above average in two groups, and there is significant difference between experimental and control groups on ICT knowledge scale. Recommendations are made for future research on online collaboration activities to raise awareness of factors related to online group work and to determine the in-service training needs of teachers on ICT use to follow-up support and to ensure successful utilization of new technologies.
\end{abstract}

Keywords: Blended learning; Technological pedagogical content knowledge (TPACK); Professional development; ICT integration; In-service teachers

\section{Introduction}

With improvement in technology, the changes in learning environment, content, and integrating ICT into classroom teaching and learning continue to be challenging tasks for many teachers (Shafer, 2008; So \& Kim, 2009). Along with digital technologies, technical competencies have also appeared. These require having knowledge and skills in using the technologies which will provide comprehensive learning. The teachers feel inadequately prepared for subject-specific use of ICT, and theoretical framework is lacking (Kramarski \& Michalsky, 2010). The TPACK framework addresses the problem from overemphasis on technological knowledge in many ICT courses that are conducted in isolation from teachers' subject matter, it is quite important that the teachers understand the nature of knowledge and inquiry in different fields (Papanikolaou et al, 2014). TPACK is a type of integrative and transformative knowledge teachers need to be effectively and adequately prepared to integrate in ICT use in the classroom.

Educational research studies show that programs of professional development for teachers are most effective when directed towards the development of ICT (UNESCO, 2002). Yet developers of online professional learning communities face significant challenges in organizing and 
maintaining a virtual community in which participants develop the sense of belonging, trust, and support which are prerequisites to learning in a community (Charalambros et al, 2004). To address the challenge of community building in online environments is to utilize a blended approach to professional development.

\section{Technological Pedagogical Content Knowledge (TPACK)}

Most recently there is recognition among many educational technologists that the pedagogical uses of technology are strongly influenced by the content domains in which they are situated. For example, the teacher knowledge required to effectively integrate technology in a science classroom may be very different from that required for a social studies classroom. TPACK framework is the interplay of three primary forms of knowledge: Content (CK), Pedagogy (PK), and Technology (TK) (Koehler \& Mishra, 2005). Based on the literature of Papanikolaou (2014), Kazua (2014), Lee (2010), Mishra and Koehler (2006), Alazzam et al (2012), Chai et al (2013), Allan et al (2010), Jimoyiannis (2010), Khan (2011), Baran et al.(2011); all studies have yielded positive results in enhancing teachers' capability to integrate ICT for instructional practice and discussed how TPACK can be used to guide educators' effort in dealing with the challenges of teaching and learning that are brought forth by rapidly changing technologies. However, there are still many potential gaps for which TPACK could be employed to facilitate deeper change in education. In particular, these studies assessed the teachers' basic ICT knowledge and skills with the presumption that any teacher of any subject will need to acquire it.

Previous studies have stated the importance of ICT knowledge as a critical factor among teachers' ICT readiness to integrate ICT into classroom teaching in their conceptual framework for teacher knowledge. The integration of ICT in education can take several forms such as information and computer networks, digital content, internet sites, multimedia, mobile technologies, multi-touch collaborative software, multi-users virtual environment etc. ICT integration can be defined as ICT use in classroom teaching. This requires understanding the representation and formulation of concepts using technologies; pedagogical techniques that utilize technologies in constructive ways to teach content according to the intersection of the three knowledge bases (Mishra \& Koehler, 2006).

The TPACK framework proposes seven distinct categories of teacher knowledge. However, in the context of this article, only the four categories (see Figure 1) found within the Technology circle (Graham et al, 2009) are discussed, as following:

- The Technological Knowledge (TK) represents the technical skills that were the early focus of educational technology courses (e.g. how to operate tools like word processing, spreadsheet, and presentation programs).

- Technological Content Knowledge (TCK) represents knowledge of technology tools and representations that are used by practitioners within a content discipline. An understanding of the manner in which technology and content influence and constrain one another (e.g. use of data collection and analysis of tools like digital probes and spreadsheets by scientists).

- Technological Pedagogical Knowledge (TPK) represents the integration of technology with general pedagogical strategies characterized by an understanding of how teaching and learning can change when particular technologies are used in particular ways (e.g. 
how to manage a technology-rich classroom, engage students with technology-oriented activities, and create useful presentations, assessments).

- Technological Pedagogical Content Knowledge (TPACK) it is at the center of the model, and it is the basis of effective teaching with technology, representing the use of technology to support content-specific pedagogical strategies (e.g. the use of technology to support science inquiry in the classroom).

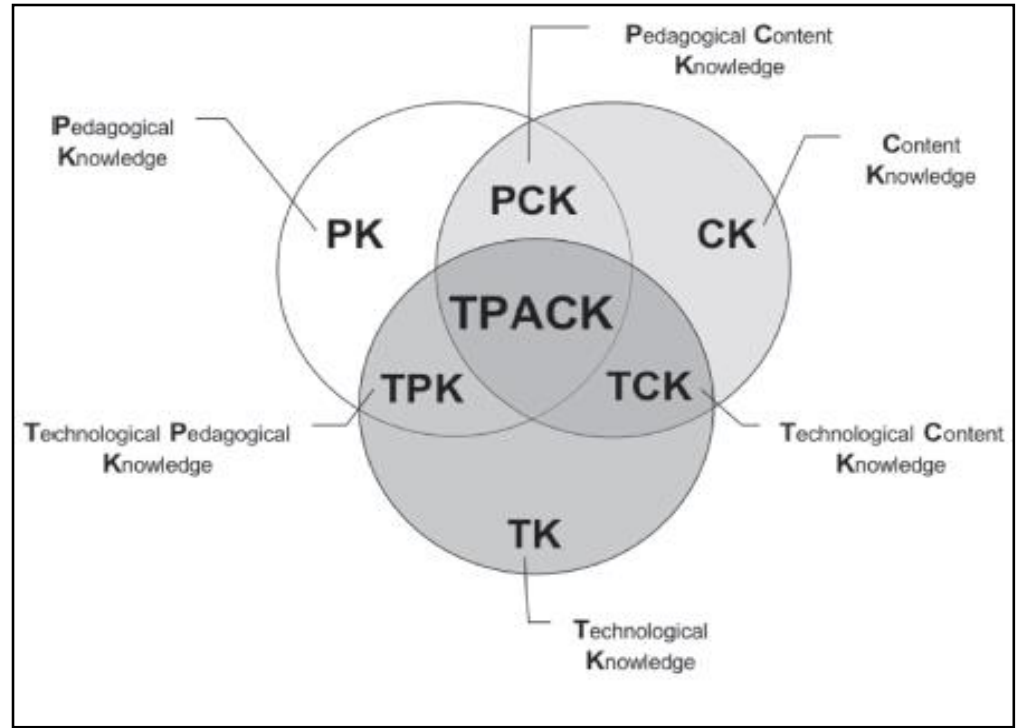

Figure 1. Visual Representation of the TPACK Framework (Graham, 2009)

\section{Professional Development through Blended Learning Approach}

Professional development is most effective (Owston, 2008), and collaborative communities are a hallmark of high quality professional development, whether they meet face-to-face (Little, 2003; Louis \& Marks, 1998; McLaughlin \& Talbert, 2001) or online (Barab, Kling, \& Gray, 2004; Koch \& Fusco, 2004). The increasing use of information technology has created renewed interest in this evolving concept (Duhaney, 2004; Vaughan, 2007). These lead to change in methods of teaching and learning.

Recently, blended learning has attracted considerable attention in teacher training programs. There are a wide variety of definitions of blended learning; the most common is that which recognizes some combination of virtual and physical environments; Owston et al (2008) described blended learning as a combination of face-to-face experiences in which learners share online experiences, although not all learners are at the same location. According to Bonk and Graham (2003), the definitions are:

- the combination of instructional modalities or delivery media and technologies.

- the combination of instructional methods, learning theories, and pedagogical dimensions.

- the combination of online learning and face-to-face learning.

Further blended learning is being adopted at all levels of the education system, as instructors explore different ways to facilitate learning, and learners become more engaged in the process within a media rich environment. This learning approach is recognized in teacher preparation 
programs as an effective way of ensuring a greater level of facility with the integration of information communication technology (ICT) across the curriculum (Duhaney, 2011).

There are significant arguments in the literature regarding adopting a blended learning approach in professional development. Owston et al. (2008) found that blended programs were effective in providing teachers with an opportunity for learning on the job and collaborating with other teachers, and that blended learning is a viable model for teachers' professional development. Papanikolaou (2014) suggested that blended programs can help teachers better understand and implement technology into their classrooms and, to a lesser extent, adapt exemplary materials to their own settings. Kaur (2013) gave the overview of the concept of blended learning from different perspectives. This study also described various blended learning strategies, disclosed the methods used in blended learning such as the synchronous instructional method and the asynchronous instructional method, and reveals the dimensions of the blended learning approach (e.g. blending offline and online learning, self-paced blending and live blending, collaborative learning, and blending structured and unstructured learning).

\section{Methodology}

\section{Purpose of Study}

This study contributes to understanding of technology usage among science teachers to design courses based on ICT knowledge and through blended learning approach. Regarding the dimensions of ICT knowledge according to TPACK framework developed by Koehler and Mishra (2006), only the four dimensions related to technology as proposed by Graham (2009) were used. The blended learning approach to teachers' professional development aimed at addressing existing gaps in teacher preparation programs. However, there is relatively limited empirical evidence on blended learning approach in teacher education programs (Abidoye, 2015; Ho et al. 2014; Keengwe \& Kang, 2013; Papanikolaou, 2014), as well they pointed out that more empirical research is needed to examine the effectiveness of blended learning in teacher training programs.

Specifically, the current study examined the dimensions of ICT knowledge according to TPACK concerning e-course design and effectiveness of blended learning on professional development for in service science teachers.

\section{Research Questions}

For this study the following research questions were examined:

Q1: What are teachers' awareness levels in TPACK scale on integrating ICT in e-course design after intervention?

Q2: Is there a significant difference between experimental group and control group regarding gain mean of teachers' TPACK on integrating ICT in e-course design?

\section{Study Design}

The present study is quasi-experimental in nature wherein a pretest-posttest non-equivalent groups design was employed. The groups are as follows: Experiment Group in which the teachers 
have been trained where blended learning environment has been provided; Control Group in which the teachers have been trained where traditional learning environment is offered.

\section{Participants}

The sample consisted of 60 science teachers in control group and experimental group (30 each). The groups matched according to the teacher's levels as indicated in their in-service training profile to use computer and Internet. The subjects were randomly assigned after matching for experimental and control groups.

\section{Instrumentation}

Knowledge scale was used to measure the teachers' ICT knowledge based on TPACK developed by Koehler and Mishra (2006). Only the four dimensions were used which were related to technology. There were 35 items, and the response for each item was assessed using a five-point Likert Scale, indicating $0=$ Not aware of the components; $1=$ Aware of the components; $2=$ Familiarly with the use of the components; $3=$ Knowledgeable about the components; 4=Highly knowledgeable about the components. Two experts in the field of computer technology were asked to validate the questionnaire for the Arabic version. The pilot test was carried out using 22 teachers, who were not included in the main study. The internal consistency and reliability of the instrument was calculated using Cronbach's coefficient alpha, and it was 0.846. Tests used as pretests and posttests have been applied to experimental and control groups to assess their ICT knowledge, After the questionnaires were collected back, the researchers analyzed them using SPSS 17.0 software.

\section{Intervention}

This study adopted a model of blended learning which was flexible; this model featured an online platform that delivers most of the curricula. Face to face instruction included 12 sessions in computer lab and online learning included 20 sessions (asynchronous and synchronous). The training program extended over 8 weeks approximately, selecting 4 days per week for 32 periods of two hour session each.

Table 1. Blended Instruction Model

\begin{tabular}{|l|l|}
\hline \multicolumn{2}{|c|}{ Time allocation for training program processes } \\
\hline Process & Session \\
\hline $\begin{array}{l}\text { Face to face } \\
\text { Project(discussion, feedback, workshop) } \\
\text { Computer assisted instruction }\end{array}$ & 12 \\
\hline $\begin{array}{l}\text { Online learning } \\
\text { Asynchronous (e-mail ,discussion, forum, Facebook) } \\
\text { Synchronous(chat, video, audio conference live in website) }\end{array}$ & 20 \\
\hline Total & \\
\hline
\end{tabular}


- Experimentation along with the computer assisted instruction was by using CD-ROM, and PowerPoint presentation. In the online platform the navigation contained the sequential elements as illustrated in Figure 2. Online learning was facilitated via a webbased learning platform (https://sites.google.com/site/alearningy/; see Figure 3). Before intervention the participants were informed about objectives of the program and session processes and they were extended invitation to join in website through their emails.

- Control group had a total of 32 sessions in the classroom and also in the computer laboratory, they had assignments which were delivered and discussed with the trainer.

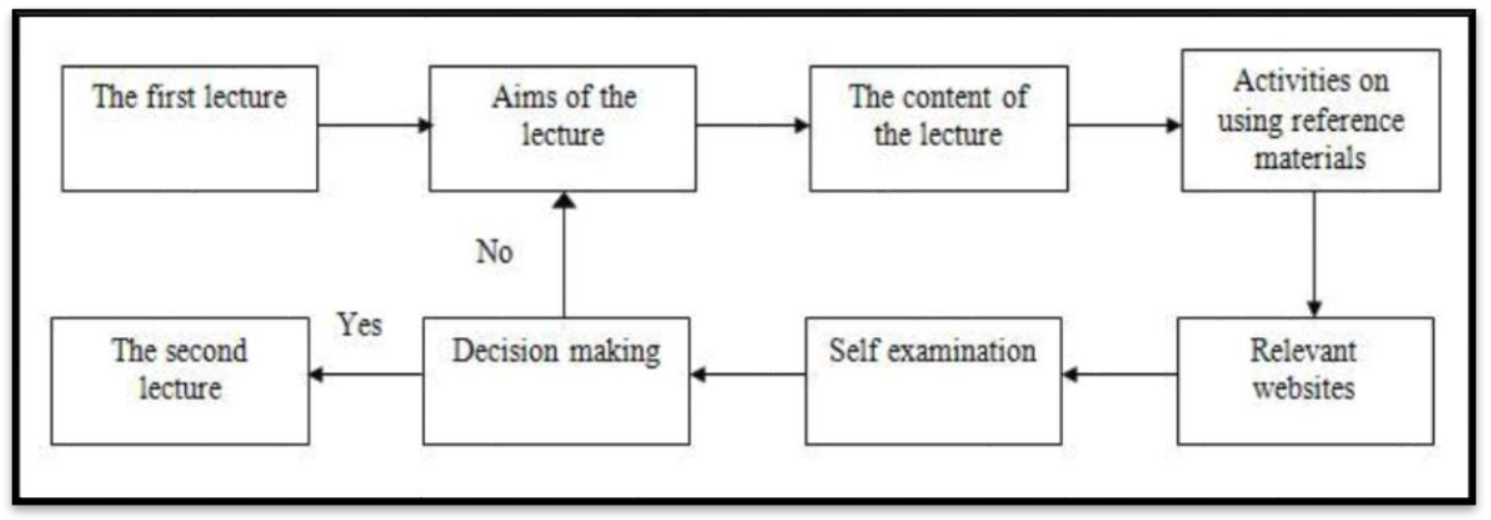

Figure 2. Scenario of Online Instructional Content

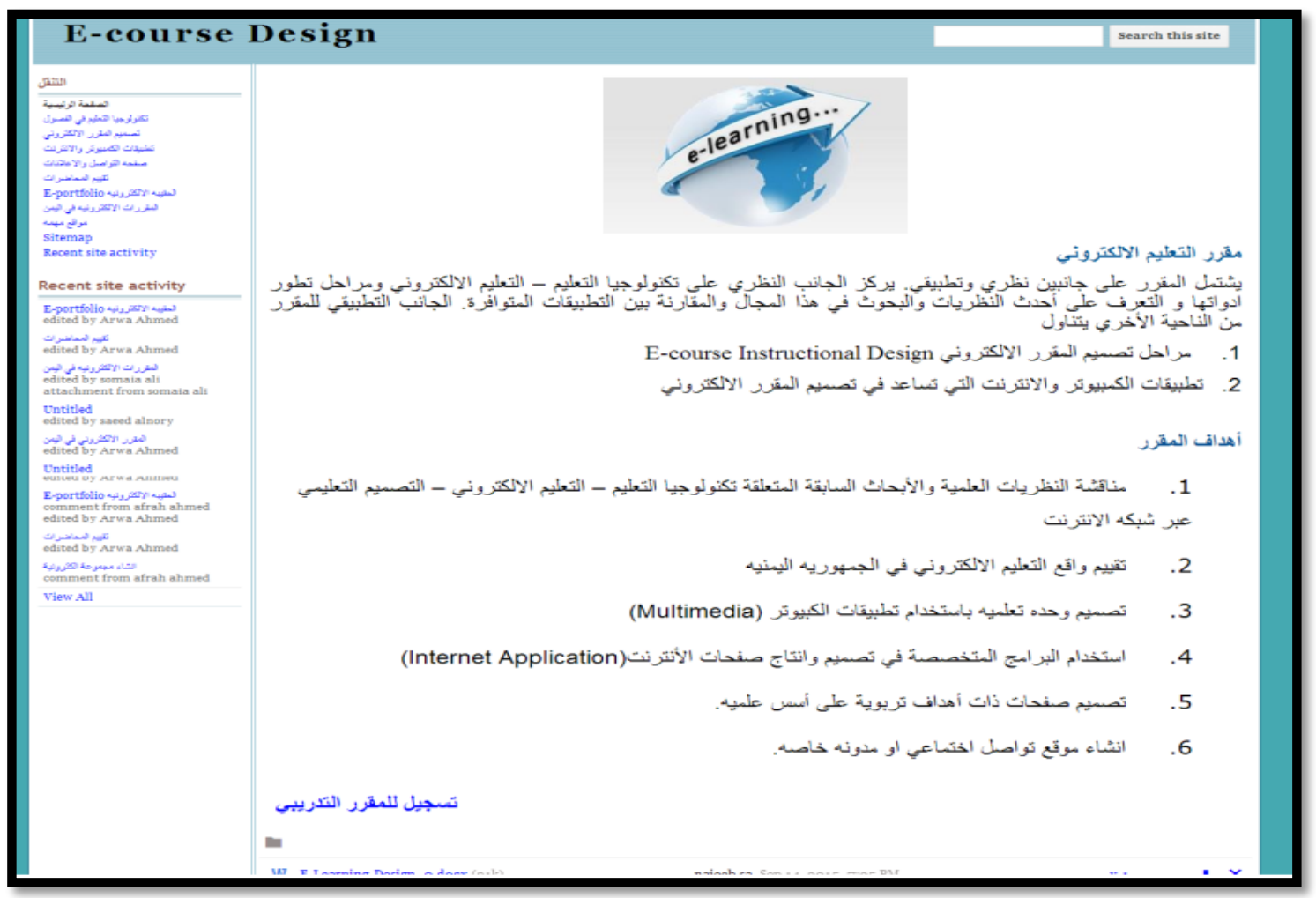

Figure 3. Screenshot of the Navigation to One Session Included Text and Hyperlinks 
For example, weekly plan sessions of four days, Figure (4) represents the strategies of the intervention for the Communication Skills.

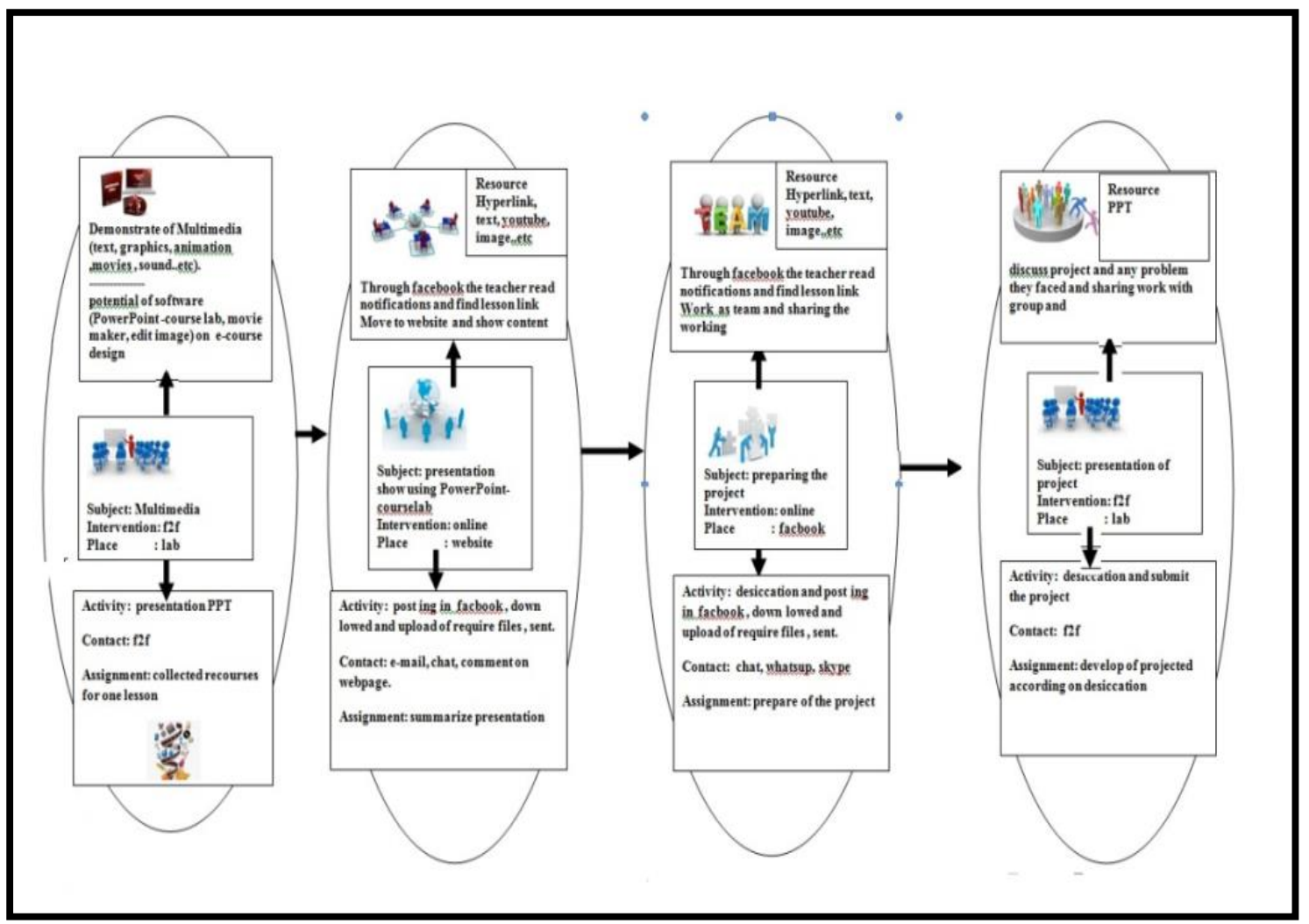

Figure 4.Four Sessions Plan for One Week

\section{Data Analysis}

Data collected through the scales were analyzed based on percentages, arithmetic means, and t-test. Findings were interpreted accordingly. For the statistical differences and relationships, a significance level of 0.05 was accepted to be sufficient.

\section{Results}

Answers the research questions "What are teachers' awareness levels in TPACK scale on integrating ICT in e-course design after intervention?" and "Is there any significant differences between experimental group and control group in gain means of teachers' TPACK on integrating ICT in e-course design?" are presented in the following tables.

\section{Equivalence between Groups before Intervention}

Table 2 summarizes the findings on the equivalence between the experiment and control groups in knowledge scores on ICT before the intervention applied in the study. 
Table 2. Equivalence between Experimental and Control Group in Pretest before Intervention on ICT Knowledge Scale

\begin{tabular}{|c|c|c|c|c|c|c|}
\hline ICT Knowledge & Group & $\mathbf{N}$ & Mean & $\begin{array}{c}\text { Std. } \\
\text { Deviation }\end{array}$ & $\begin{array}{l}\text { Levene } \\
\text { Statistic }\end{array}$ & $\begin{array}{l}\text { Sig }(p- \\
\text { value) }\end{array}$ \\
\hline \multirow{2}{*}{ Technological Knowledge (TK) } & experimental & 30 & 9.50 & 2.596 & \multirow{2}{*}{1.354} & \multirow{2}{*}{0.249} \\
\hline & Control & 30 & 9.87 & 3.277 & & \\
\hline \multirow{2}{*}{$\begin{array}{l}\text { Technological Pedagogical } \\
\text { Knowledge (TPK) }\end{array}$} & experimental & 30 & 6.53 & 2.177 & \multirow[b]{2}{*}{0.661} & \multirow[b]{2}{*}{0.419} \\
\hline & Control & 30 & 7.70 & 2.521 & & \\
\hline \multirow{2}{*}{$\begin{array}{l}\text { Technological Content } \\
\text { Knowledge (TCK) }\end{array}$} & experimental & 30 & 8.67 & 2.604 & \multirow{2}{*}{0.167} & \multirow{2}{*}{0.658} \\
\hline & Control & 30 & 8.60 & 2.175 & & \\
\hline \multirow{2}{*}{$\begin{array}{l}\text { Technological Pedagogical } \\
\text { Content Knowledge (TPACK) }\end{array}$} & experimental & 30 & 9.93 & 1.660 & \multirow{2}{*}{0.16} & \multirow{2}{*}{0.900} \\
\hline & Control & 30 & 9.03 & 1.829 & & \\
\hline
\end{tabular}

An examination of Levene's Statistic results in Table 2 reveals that there is no significant difference between the groups regarding their ICT knowledge scores $(p>0.05)$. It is indicated that the groups were equivalent in their ICT knowledge scores; to put it differently it has been observed that the teachers in the two groups were close to each other when their ICT knowledge scores are considered.

\section{Effectiveness of Blended Learning on ICT Knowledge Scores based on TPACK}

Based on the t-test results, a significant difference was found between the experimental group and the control group in the gain means on ICT knowledge, and the results for both groups are tabulated in Table 3.

Table 3.Comparison of Mean Scores between Experimental and Control Group in Pretest and Posttest of ICT Knowledge Scale

\begin{tabular}{|c|c|c|c|c|c|c|c|}
\hline Variable & Group & No & $\begin{array}{c}\text { Pretest } \\
\text { Mean }\end{array}$ & $\begin{array}{c}\text { Posttest } \\
\text { Mean }\end{array}$ & $\begin{array}{c}\text { “t” } \\
\text { Pre-post }\end{array}$ & df & Sig. \\
\hline $\begin{array}{c}\text { Technological Knowledge } \\
\text { (TK) }\end{array}$ & Experimental & 30 & 9.50 & 35.67 & 35.222 & 29 & .000 \\
\cline { 2 - 8 } & Control & 30 & 9.87 & 31.97 & 20.129 & 29 & .000 \\
\hline $\begin{array}{c}\text { Technological } \\
\text { Pedagogical Knowledge } \\
\text { (TPK) }\end{array}$ & Experimental & 30 & 6.53 & 35.33 & 39.540 & 29 & .000 \\
\cline { 2 - 8 } & Control & 30 & 7.70 & 30.40 & 25.052 & 29 & .000 \\
\hline $\begin{array}{c}\text { Technological Content } \\
\text { Knowledge (TCK) }\end{array}$ & Experimental & 30 & 8.60 & 29.17 & 40.364 & 29 & .000 \\
\cline { 2 - 8 } & Control & 30 & 8.60 & 29.17 & 23.038 & 29 & .000 \\
\hline $\begin{array}{c}\text { Technological } \\
\text { Pedagogical Content } \\
\text { Knowledge (TPACK) }\end{array}$ & Experimental & 30 & 9.93 & 25.70 & 27.059 & 29 & .000 \\
\cline { 2 - 8 } & Control & 30 & 9.03 & 21.87 & 16.597 & 29 & .000 \\
\hline
\end{tabular}


Table 3 indicates that there are significant differences between mean scores on pretest and posttest at 0.05 level of confidence on ICT Knowledge (TK, TPK, TCK, and TPACK). When the findings are interpreted, on pretest and posttest components of the TPACK scale administered to both groups, the teachers were found to be significantly different in terms of all the subcomponents of the scale (Technology Knowledge, Technological Pedagogical Knowledge, Technological Content Knowledge, Technological Pedagogical Content Knowledge).

For all the subcomponents of the scale, the teachers' posttest scores have shown an improvement over the pretest scores. The table also indicates that the mean gain scores of experimental group are higher than those of the control group on ICT knowledge (TK, TPK, TCK, and TPACK). To examine which method was better than the other, the gain mean used for comparison between experimental group (blended learning approach) and control group (traditional method); t-test was performed to check the difference on ICT knowledge scale scores in gain mean between the two groups. The results are presented in Table 4.

Table 4.Comparison of the Gain Mean between Experimental and Control Group on ICT Knowledge Scale

\begin{tabular}{|c|c|c|c|c|c|c|c|}
\hline ICT Knowledge & group & $\mathbf{N}$ & $\begin{array}{l}\text { Mean } \\
\text { Gain }\end{array}$ & SD & $\mathbf{t}$ & df & $\begin{array}{c}\text { Sig. } \\
\text { (2-tailed) }\end{array}$ \\
\hline \multirow{2}{*}{$\begin{array}{l}\text { Technological } \\
\text { Knowledge (TK) }\end{array}$} & Experimental & 30 & 26.1667 & 4.06909 & \multirow{2}{*}{3.068} & \multirow{2}{*}{58} & \multirow{2}{*}{.003} \\
\hline & Control & 30 & 22.1000 & 6.01349 & & & \\
\hline \multirow{2}{*}{$\begin{array}{c}\text { Technological } \\
\text { Pedagogical Knowledge } \\
\text { (TPK) }\end{array}$} & Experimental & 30 & 29.0000 & 4.01720 & \multirow[b]{2}{*}{5.404} & \multirow[b]{2}{*}{58} & \multirow[b]{2}{*}{.000} \\
\hline & Control & 30 & 22.7000 & 4.96297 & & & \\
\hline \multirow{2}{*}{$\begin{array}{l}\text { Technological Content } \\
\text { Knowledge (TCK) }\end{array}$} & Experimental & 30 & 23.9333 & 3.24763 & \multirow{2}{*}{3.141} & \multirow{2}{*}{58} & \multirow{2}{*}{.003} \\
\hline & Control & 30 & 20.5667 & 4.88970 & & & \\
\hline \multirow{2}{*}{$\begin{array}{c}\text { Technological } \\
\text { Pedagogical Content } \\
\text { Knowledge (TPACK) }\end{array}$} & Experimental & 30 & 15.7667 & 3.19140 & \multirow[b]{2}{*}{3.030} & \multirow[b]{2}{*}{58} & \multirow[b]{2}{*}{.004} \\
\hline & Control & 30 & 12.8333 & 4.23518 & & & \\
\hline
\end{tabular}

Table 4 reveals a significant difference $(t=3.068, p<0.05)$ on gain mean of $T K$, and the gain mean score in TK is higher in the experimental group ( $M=26.167)$ when compared to the control group $(M=22.1)$. The results indicate that there is a significant difference between the groups in gain mean on ICT knowledge.

Table 4 shows a significant difference $(t=5.404, p<0.05$ ) on gain mean of TPK; it is evident that the gain mean scores in TPK is higher in the experimental group $(M=29.00)$ when compared to the control group $(\mathrm{M}=22.70)$.

Table 4 demonstrates that there is a significant difference between the groups in gain mean on ICT knowledge. It reveals $(t=3.141, p<0.05)$ on gain mean of TCK, and the gain mean scores in TCK is higher in the experimental group $(M=23.93)$ when compared to the control group $(\mathrm{M}=20.57)$. 
Finally, Table 4 shows that there is a significant difference between the groups in gain mean on ICT knowledge. It reveals $(t=3.030, p<0.05$ ) on gain mean of TPACK. It is evident that the gain mean score in TPACK is higher in the experimental group $(M=15.77)$ when compared to the control group ( $\mathrm{M}=12.83)$.

The gain means both on pretest and posttest on ICT knowledge scale of the groups are shown comparatively in Figure 3. It demonstrates that the gain mean scores of ICT knowledge are consistently higher in the experimental group than the control group.

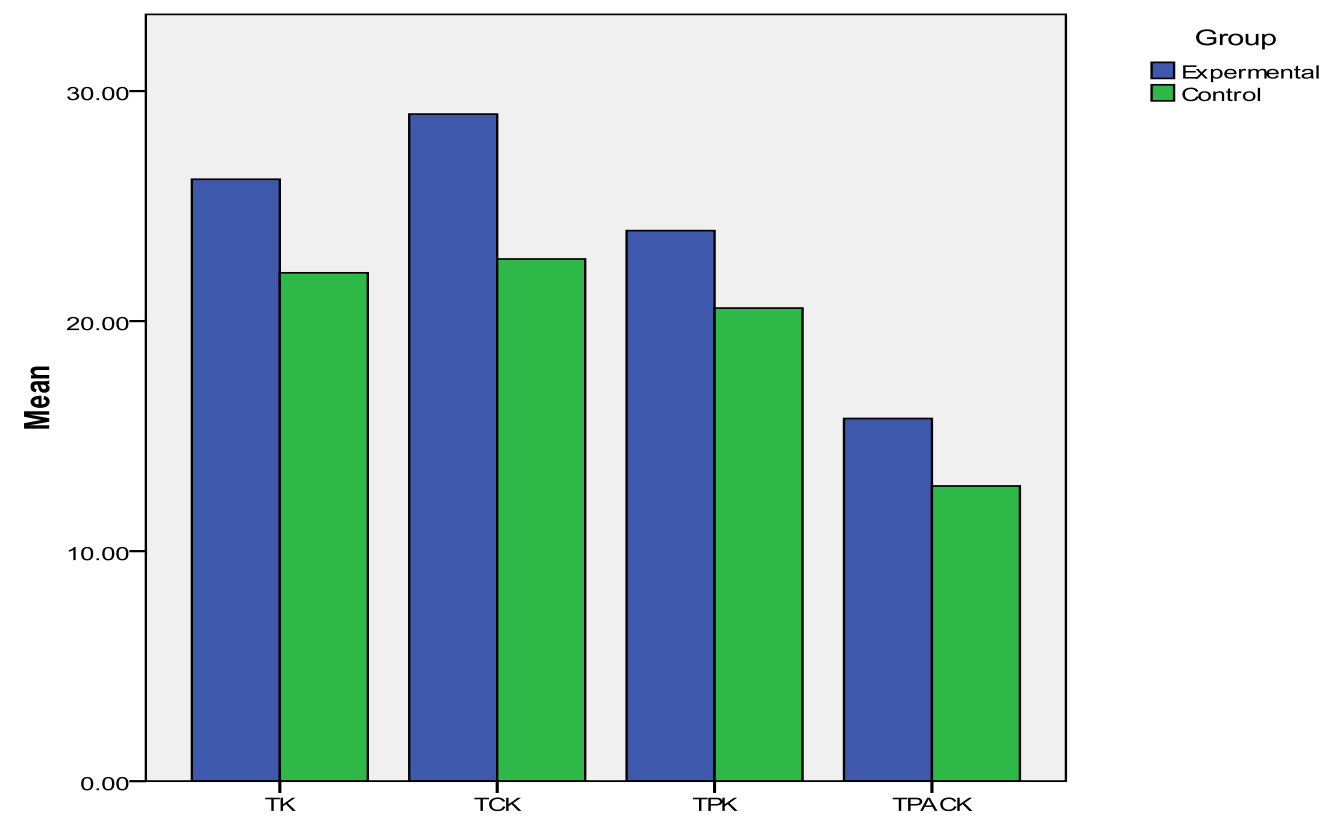

Figure 3.Gain Means in ICT Knowledge among Groups

\section{Discussion and Conclusion}

Results of this study indicated that the teachers' ICT knowledge was above the general average in the two groups. It could be attributed to the knowledge of new technology merged with teachers' content and pedagogical knowledge, which might have contributed in teachers' awareness level on ICT knowledge to integrate ICT in e-course design. It can be assumed that the participants had already acquired the necessary knowledge of ICT usage after the intervention. This result is consistent with the findings of the studies done by Baran et al. (2011), Papanikolaou (2014), Sezer (2015), and Tozkoparan et al. (2015) who all found that TPACK model plays a leading role on the subject of teachers' needs about technology, pedagogy and content in order to ensure professional development of teachers. Ultimately, TPACK has provided a valuable tool for assessing teacher knowledge in the area of technology integration. This result will make positive contributions to integrate ICT and improve teachers' performance in the learning process. 
When Table 4 is carefully reviewed, it is seen that there are differences between groups regarding gain mean on ICT knowledge. That means that the experimental group which was trained through blended learning performed higher than the control group which was trained through traditional method on ICT knowledge in e-course design. It could be attributed to that the teachers who were trained through blended learning approach have expressed their satisfaction with the enhanced interaction and flexibility which this environment affords along with the opportunities for continuous improvement; these points were observed through their posting during activities. This result supports Kaur (2013) and Adidoye (2015) who found that blended learning instructional approach was more effective in enhancing teachers' performance compared to conventional teaching method.

In conclusion, regarding the teachers' ICT knowledge, the findings of this study point out that the developers for teacher preparation programs must be careful in identifying appropriate ways to apply ICT tools throughout the coursework and experiences planned for in-service teachers. Teachers should continue to improve and gain more ICT knowledge. The study suggests comparative research into the strengths and weaknesses of different ICTs, especially the new technologies integrated with face-to-face environments available for teachers in schools, to investigate the characteristics of best blends for learning. Finally, as there is a lack of empirical research on the application of blended learning to teachers' professional development in Yemen, the current study will be useful to educators, researchers, and teachers. It will be also helpful for educators on how to design e-learning experiences, to develop new and alternative methods to traditional methods of training in accommodating the necessary training needs of teachers.

\section{References}

Abidoye J. A. (2015). The effect of blended learning instructional approach on secondary school students academic achievement in geography in Akure, Ondo State, Nigeria, Research Journal of Educational Studies and Review, 1(5), 106-110.

Alazzam, B. (2012). Effects of demographic characteristics, educational background, and supporting factors on ICT readiness of technical and vocational teachers in Malaysia, International Education Studies, 5(6), 229-243.

Allan, W. C., Erickson, J. L., Brookhouse, P., \& Johnson, J. L. (2010). Teacher professional development through a collaborative curriculum project- an example of TPACK in Maine. TechTrends, 54(6), 36-43.

Barab, S. A., Kling, R., \& Gray, J. (2004). (Eds.). Designing for virtual communities in the service of learning. Cambridge: Cambridge University Press.

Baran, E., Chuang, H., \& Thompson, A. (2011). TPACK: An Emerging Research and Development Tool for Teacher Educators, Turkish Online Journal of Educational Technology, 10(4), 370-377.

Bonk \& C. J. \& Graham, C. R (Eds.). (2003). The handbook of blended learning: Global perspectives, local designs (pp. 338-349). San Francisco: Pfeiffer.

Chai, C.-S., Koh, J. H. L., \& Tsai, C.-C. (2013). A Review of Technological Pedagogical Content Knowledge. Educational Technology \& Society, 16(2), 31-51. 
Charalambos, V., Michalinos, Z., \& Chamberlain, R. (2004). The design of online learning communities: Critical issues. Educational Media International, 41(2), 135-143.

Duhaney, D. C. (2004). Blended learning in education, training, and development. Performance Improvement, 43(8), 35-38.

Graham, C. R., Burgoyne, N., Cantrell, P., Smith, L., Clair St., L., \& Harris, R. (2009). TPACK development in science teaching: Measuring the TPACK confidence of in-service science teachers. TechTrends, 53(5), 70-79.

Ho, V., Nakamoria, Y., Ho, T., \& Ho, S. (2013). Study on A Model for Teacher Professional Development In Vietnam Based On Knowledge Management. Proceedings of the 57th annual meeting of the ISSS. HaiPhong, Vietnam

Jimoyiannis, A. (2010). Designing and implementing an integrated technological pedagogical science knowledge framework for science teachers' professional development. Computers \& Education, 55(3), 1259-1269.

Kaur, M. (2013). Blended learning - Its challenges and future. Procedia - Social and Behavioral Sciences, 93, 612-617. (3rd World Conference on Learning, Teaching and Educational Leadership). doi:10.1016/j.sbspro.2013.09.248

Kazua, I. \& Demirkol, M. (2014). Effect of blended learning environment model on high school students' academic achievement. The Turkish Online Journal of Educational Technology 13(1).

Keengwe, J. \& Kang, J. (2013). Blended learning in teacher preparation programs: A literature review. International Journal of Information and Communication Technology Education, $18,479-493$

Khan, S. (2011). New pedagogies on teaching science with computer simulations. Journal of Science Education \& Technology, 20(3), 215-232. doi:10.1007/s10956-010-9247-2.

Koch, M. \& Fusco, J. (in press). Designing for growth: Enabling communities of practice to develop and extend their work online. In C. Kimble, P. Hildreth, \& I. Bourdon (Eds.), Communities of Practice: Creating Learning Environments for Educators. Charlotte, NC: Information Age.

Koehler, M. J. \& Mishra, P. (2005). What happens when teachers design educational technology? The development of technological pedagogical content knowledge. Journal of Educational Computing Research, 32(2), 131-152.

Kramarski, B. \& Michalsky, T. (2010). Preparing preservice teachers for self-regulated learning in the context of technological pedagogical content knowledge. Learning and Instruction, 20(5), 434-447.

Lee J. (2010). Design of blended training for transfer into the workplace. British Journal of Educational Technology, 41(2), 181-198.

Little, J. W. (2003). Inside teacher community: Representations of classroom practice. Teachers College Record, 105(6), 913-945.

Louis, K. S. \& Marks, H. (1998). Does professional community affect the classroom? Teachers' work and student experiences in restructuring schools. American Journal of Education, 106, 32-575.

McLaughlin, M. \& Talbert, J. (2001). Professional communities and the work of high school teaching. Chicago: University of Chicago Press. 
Mishra, P. \& Koehler, M. J. (2006). Technological pedagogical content knowledge: A framework for teacher knowledge. Teachers College Record, 108(6), 1017-1054.

Owston, R., Wideman, H., \& Murphy, J. (2008). Blended learning for professional development in diverse urban settings: Findings from three project evaluations. Paper presented at the Annual Meeting of the American Educational Research Association. New York City.

Papanikolaou, K., Gouli, E., \& Makri, K. (2014). Designing pre-service teacher training based on a combination of TPACK and Communities of Inquiry. Proceedings of the 5th World Conference on Educational Sciences (WCES-2013). Procedia - Social and Behavioral Sciences, 116, 3437-3442.

Sezer, B. (2015). Examining technopedagogical knowledge competencies of teachers in terms of some variables. Procedia - Social and Behavioral Sciences, 174, 208-215

Shafer, K. G. (2008). Learning to teach with technology through an apprenticeship model. Contemporary Issues in Technology \& Teacher Education, 8(1), 27-44.

So, H. \& Kim, B. (2009). Learning about problem based learning: Student teachers integrating technology, pedagogy and content knowledge. Australasian Journal of Educational Technology, 25(1), 101-116.

Tozkoparan, S., Kilic, M., \& Usta, E. (2015).The effect of instructional technology and material design course to teacher candidates' gaining of technological pedagogical content knowledge competencies. Participatory Educational Research, 2(1), 44-56.

UNESCO. (2002). Information and communication technology in education- $A$ curriculum for schools and programme of teacher development. Paris: UNESCO.

Vaughan, N. (2007). Perspectives on blended learning in higher education. International Journal on E-Learning, 6(1), 81-94.

Correspondence: Arwa Ahmed Abdo Qasem, Ph.D., Research Scholar, University of Mysore, Mysuru, Karnataka, India 